\title{
Contribution to the knowledge of Podischnus Burmeister, 1847 (Coleoptera: Melolonthidae: Dynastinae) with the description of two new species from Brazilian Amazon Forest
}

\author{
Paulo Roberto Marinho Duarte ${ }^{1,2}$ \& Paschoal Coelho Grossi ${ }^{1,3}$ \\ 1 Universidade Federal Rural de Pernambuco (UFRPE), Departamento de Agronomia (DEPA), Laboratório de Taxonomia de Insetos. \\ Recife, PE, Brasil. \\ 2 ORCID: http://orcid.org/0000-0003-1991-8068.E-mail: duartepaul085@gmail.com \\ ${ }^{3}$ ORCID: http://orcid.org/0000-0001-6601-5967.E-mail: paschoal.grossi@gmail.com
}

\begin{abstract}
Two new Podischnus Burmeister, 1847 species are described here: Podischnus limeirai sp. nov. from Gurupi region, Maranhão state, Brazil, the easternmost distribution of the genus; and Podischnus cleidecostae sp. nov. from the Acre state, Western of Brazilian Amazon Forest. New diagnostic characters are illustrated and discussed for the genus. An illustrated identification key for all Podischnus species, and an up-to-date distribution map for the Brazilian species of Podischnus are provided. Moreover, we propose the inclusion of $P$. limeirai sp. nov. in the Red List of Threatened Species (IUCN) due to the fast loss of the Oriental Amazon Forest remnant fragment in that region.
\end{abstract}

Key-Words. Deforestation; New taxa; South America; Oryctini; Threatened species.

\section{INTRODUCTION}

The genus Podischnus Burmeister can be distinguished from other Neotropical Oryctini genera by the elongated body, subparallel elytra, emarginated and broad clypeus, bidentate mandibles, quadridentate protibiae (teeth projecting at nearly right angles), and tergite VII (= propygidium) with two stridulatory areas (Endrödi, 1976; Ratcliffe \& Morón, 1997). Podischnus species also exhibit a strong sexual dimorphism and allometric development, with major males presenting exuberating elongate horns, while minor males present smaller horns, and females with only a cephalic conical tubercle (Ratcliffe \& Morón, 1997; Ratcliffe \& Cave, 2006).

Currently, three species of Podischnus are known, all occurring in South America, with only Podischnus agenor (Olivier, 1789) distributed also throughout Central America up to Mexico (Ratcliffe \& Morón, 1997), while Podischnus oberthuri Sternberg, 1907 is distributed in the Andean Region (Endrödi, 1985). In Brazil two species are known, found at Acre, Amazonas, Pará, and Rondônia states: Podischnus sexdentatus (Taschenberg, 1870) and P. agenor (Gasca-Álvarez et al., 2008; Grossi \& Vaz-de-Mello, 2019).

Most of Podischnus species has its natural history unclear and there is only one study about the biological aspects of $P$. agenor performed by Eberhard (1979). Also, Neita-Moreno \& Orozco (2009) described the larva and pupa of this species with a brief note about its natural history.

As a part of our studies on Neotropical phytophagous scarab beetles, we describe here two new unusual Podischnus species from Brazilian Amazon: one from Maranhão state, Gurupi region, eastern Amazon, located within Belém endemism area, and other from Acre state, Madeira province, west Amazon (Morrone, 2006). A known distribution map for these new species along with the other two Brazilian ones is provided, as well as an illustrated identification key for all Podischnus species. Furthermore, due to the fast deforestation of the remaining medium-sized fragment of the Amazon forest at Maranhão state, is proposed the inclusion of the new species described for the Gurupi region in the Red list of Threatened Species (IUCN). 


\section{MATERIAL AND METHODS}

We were able to study 29 specimens of Podischnus from the following collections: CERPE: Coleção Entomológica da Universidade Federal Rural de Pernambuco, Recife, Brazil (Paschoal C. Grossi); CEMT: Seção de Entomologia da Coleção Zoológica da Universidade Federal do Mato Grosso, Cuiabá, Brazil (Fernando Z. Vaz-de-Mello); CZMA: Coleção Zoológica do Maranhão, Universidade Estadual do Maranhão, Caxias, Brazil (Francisco L. Oliveira); DZUP: Coleção Entomológica Pe. Jesús Santiago Moure, Departamento de Zoologia, Universidade Federal do Paraná, Curitiba, Brazil (Lúcia M. de Almeida); EPGC: Everardo and Paschoal Grossi Collection, Nova Friburgo, Brazil (Everardo J. Grossi).

The specimens were examined under a Zeiss Stemi 508 stereomicroscope with a LED light. Illustrations were made using a stereomicroscope Olympus SZX12 with lucid camera. Photographs were obtained using a Nikon D90 digital camera with $40 \mathrm{~mm}$ Macrolens commanded by the software Helicon Remote version 3.8.1 and combined with the software Combine ZP version 1.0. Male specimens were boiled in hot water for aedeagi extraction, which were cleaned, card-mounted, and pinned bellow the specimen. For measurements a digital pachymeter was used. Measures were obtained based on body length from clypeal apex to elytral apex, and body width as the distance across humeri. Distribution map was elaborated using Simplemappr online tool (Shorthouse, 2010), based on the examined material and data from Gasca-Álvarez et al. (2008). Terminology follows Lawrence et al. (2011) for overall morphology and Endrödi (1985) for male genitalia. Classification system is based on Cherman \& Morón (2014).

\section{RESULTS}

\section{Podischnus agenor (Olivier, 1789)}

(Figs. 1A; 2A; 5A; 6A; 7A; 8A; 9B, D, F; 10)

Scarabaeus agenor Olivier, 1789: 178.

Scarabaeus barbicornis Latreille, 1813: 201; Endrödi, 1976: 55 (syn.).

Podischnus propiquus Prell, 1911: 200; Endrödi, 1976: 55 (syn.).

Examined material: COSTA RICA: Cartago, Turrialba, 600 m, 10.III.1973, V.O Becker Col. (1 o', CERPE). COLOMBIA: CHOCÓ: Quibdó, Corregimiento de Tutunendó, Vereda Cara de Perro, $\left(05^{\circ} 45^{\prime} 07.9^{\prime \prime} \mathrm{N}, 76^{\circ} 45^{\prime} 16.8^{\prime \prime} \mathrm{W}\right), 340 \mathrm{~m}, \mathrm{XII.2009}$, Luz Negra, J.C. Neita (1 $\sigma^{\star}, 1$ \%, CEMT). BOYACÁ:Muzo, 22.XII.1987, Reinhard Foerster leg (1 $\sigma^{\prime}$, CERPE); no data ( $1 \sigma^{\prime}, 1$, DZUP). HUILA, Neiva, Rio Yari, 06.VI.2002, L.C.P. Locamo Leg. (1 $q$, EPGC). ECUADOR: SUCUMBIOS:Tarapos, MPF city, $300 \mathrm{~m}$, no date, mechero de petrolera, Pablo Araújo Leg. (1 ơ, CERPE).

Geographical distribution: Mexico, Belize, Guatemala, Honduras, El Salvador, Nicaragua, Costa Rica, Panama, Venezuela, Colombia, French Guiana, Brazil (Fig. 10), Ecuador and Peru.
Podischnus sexdentatus (Taschenberg, 1870)

(Figs. 1B; 2B; 3A, C; 4A, C; 5B; 6B; 7B; 8B; 9E; 10)

Heterogomphus sexdentatus Taschemberg, 1870: 186. Podischnus beckeri Sternberg 1907: 347; Prell, 1911: 203 (syn.).

Examined material: COLOMBIA: HUILA: Neiva, Rio Yari, 06.VI.2002, L.C.P. Locamo Leg. (1 o', EPGC). CAQUETA:Yari, 28.VI.1990, Reinhard Foerster (1 $\sigma^{*}$, EPGC). ECUADOR: ESMERALDAS: Rio Santiago, Playa de Oro, 28.VI.2001, Fumigación, LOTE 1079, Pablo Araujo et al. Leg. (1 \&, CEMT). No data - (DZUP).

Geographical distribution: Colombia, Brazil (Fig. 10), Ecuador and Peru.

\section{Podischnus oberthuri Sternberg, 1907 (Figs. 1C; 2C; 5C; 6C; 7C; 8C; 9C; 10)}

Podischnus oberthuri Sternberg 1907: 343.

Podischnus horni Sternberg 1907: 349; Endrödi, 1976: 55 (syn.).

Examined material: ECUADOR: ORELLANA: Coca, Puerto Francisco de Orellana, 03.I.2003 (1 $\sigma^{\star}$, EPGC). PERU: CUZCO: $20 \mathrm{~km}$ from Southwest of Quincemil, $\left(13.355^{\circ} \mathrm{S}\right.$, $\left.70.889^{\circ} \mathrm{W}\right), 985$ m, 23.VIII.2012, Cavichioli, Melo, Rosa \& Santos Leg. (1 \&, CERPE); Mina de Sol, III.2008, Berndt Cavelius Leg. (1 o", CERPE).

Geographical distribution: Ecuador, Peru and Bolivia.

\section{Podischnus limeirai sp. nov. (Figs. 1D; 2D; 3B, D; 5D; 6D; 7D; 8D; 9A; 10)}

Type material: HOLOTYPE ơ (CERPE), not dissected, labeled: "BRASIL: MARANHÃO: Araguanã, Alto Rio Turiaçu, Reserva Indígena Awaguajá, Armadilha Luminosa, 17-20. III.2002, Limeira-de-Oliveira \& J.T Câmara Cols. (CERPE)". PARATYPES: 3 males and 2 females with same data as holotype - (1 o', 1 \%, EPGC; 1 o', 1 \%, CEMT; 1 o", CZMA); "Bom Jardim, Reserva Biológica Gurupi, 01-06.III.2011, Limeirade-Oliveira \& J.A. Silva Cols." (1 \&, CERPE).

Diagnosis: Podischnus limeirai sp. nov. is distinguished from other Podischnus species by the following combination of characters: metafemora with a row of setigerous punctures near anterior margin (Fig. 3D) and tergite VII with arched stridulatory bands in both sexes (Fig. 5D). Males with clypeal apex with no border in front of cephalic horn in dorsal view (Fig. 3B); cephalic horn toothless (Fig. 2D); pronotal horn with rounded anterior corners in dorsal view (Fig. 1D) and dorsoventrally rounded in lateral view (Fig. 2D); parameres with narrow outer margins in dorsal view (Fig. 6D), and with outer sides visible in ventral view (Fig. 7D). Females with anterior pronotal border medially narrow (Fig. 9A). 

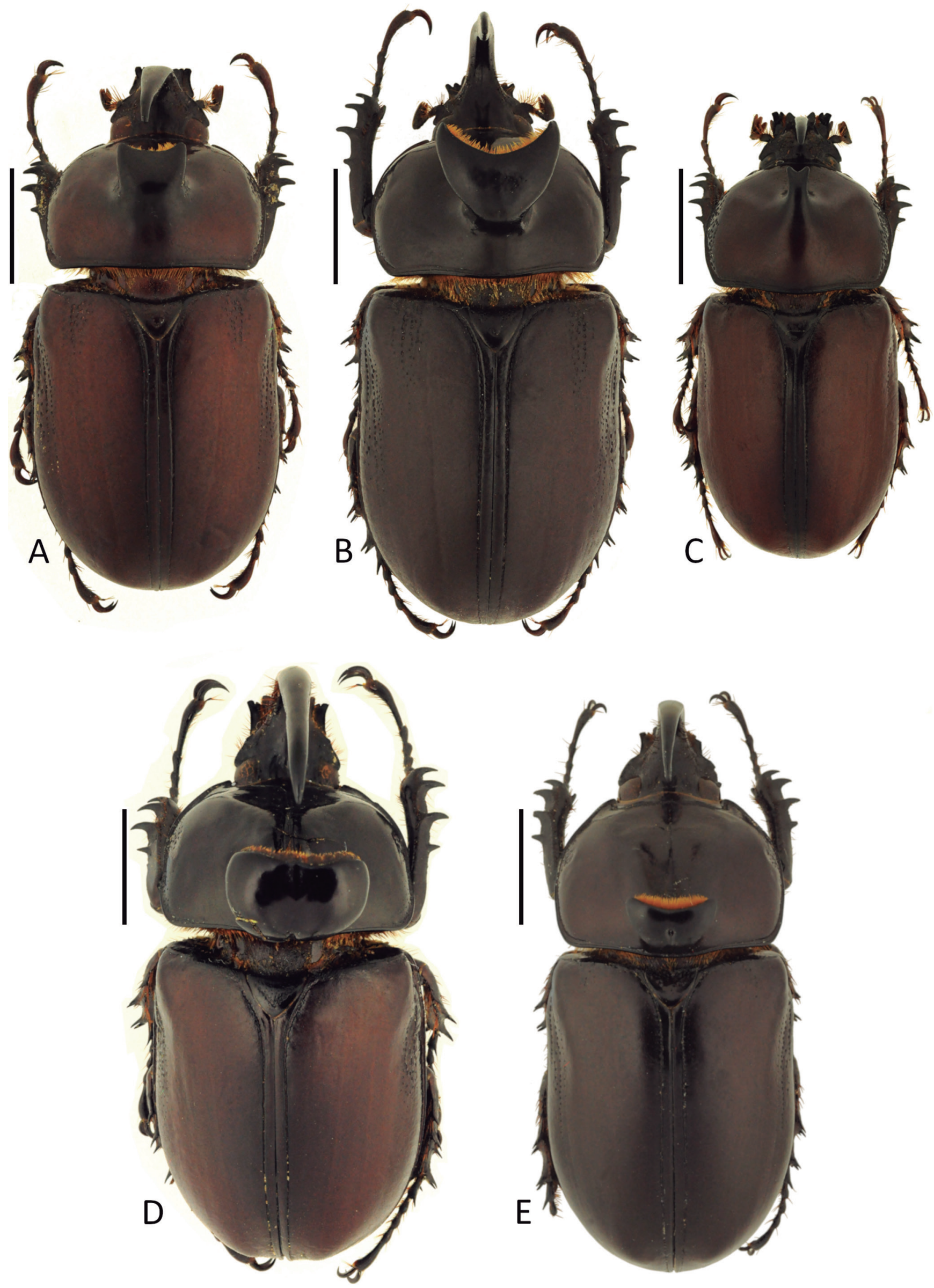

Figure 1. Podischnus Burmeister species (male), habitus dorsal: (A) P. agenor (Olivier). (B) P. sexdentatus (Taschenberg). (C) P. oberthuri Sternberg. (D) P. limeirai sp. nov. (E) P. cleidecostae sp. nov. Scale bars: $2 \mathrm{~mm}$. 

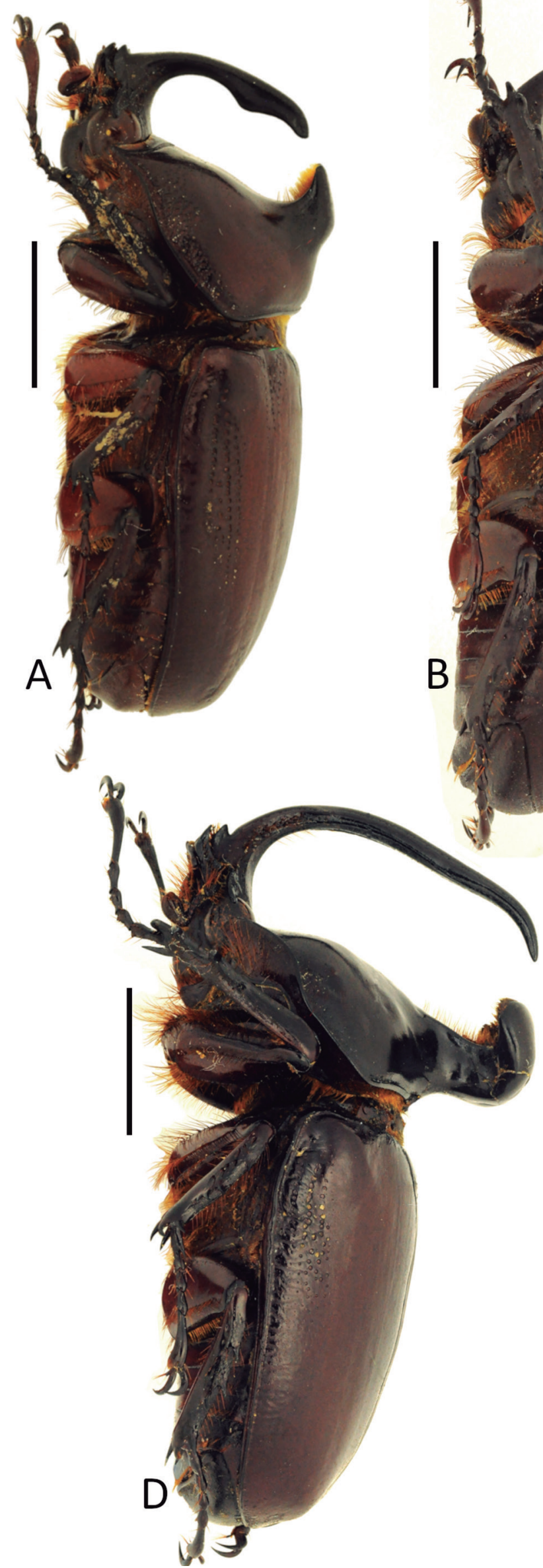
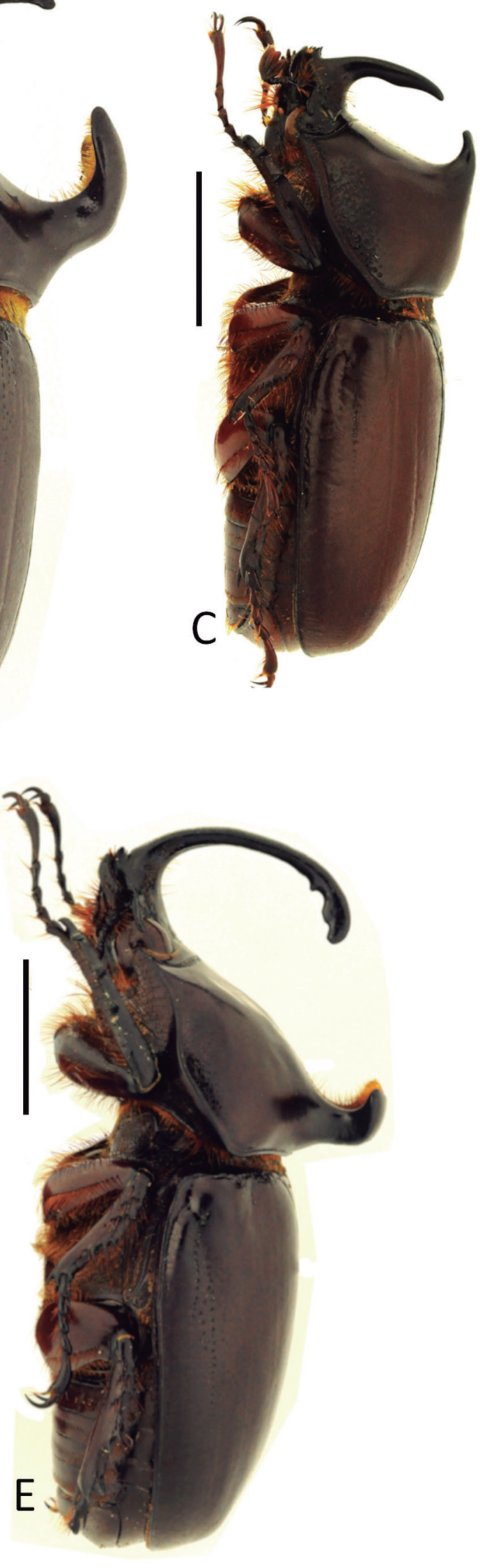

Figure 2. Podischnus Burmeister species (male), habitus lateral: (A) P. agenor (Olivier). (B) P. sexdentatus (Taschenberg). (C) P. oberthuri Sternberg. (D) P. limeirai sp. nov. (E) P. cleidecostae sp. nov. Scale bars: $2 \mathrm{~mm}$. 


\section{Holotype, male description}

Body length: $44.5 \mathrm{~mm}$.

Body width: $21.0 \mathrm{~mm}$.

Color: Surface almost completely reddish brown, only with tibial teeth darker.

Head: Clypeus bidentate; teeth separated in dorsal view by a broad, emarginated apex (Fig. 3B); horn at the subapical area long, curved backwards, acuminated apically; horn laterally covered by setigerous, basal punctures. Frons smooth at middle, only with few small punctures confined to the sides; interocular width $1.2 \times$ the transverse diameter of the eye. Eye canthus subtriangular, excavated, glabrous. Antennae with 10 antenomeres; club subequal in length to antennomeres 2-7; 1-4 cylindrical, 5-7 subquadrate. Mandibles bidentate; external margin exposed laterally to clypeus in dorsal view; outer tooth stronger than inner tooth. Mentum convex, base with sides rounded, narrowed towards apex, apex widened; surface moderately punctate, punctures setose.

Pronotum: Pronotal horn bent backwards in lateral view (Fig. 2D); horn base abruptly narrowed in posterior view; apex very broad, about four times wider than the basal width; in dorsal view slightly emarginate anteriorly (Fig. 1D), with anterior corners rounded; posteriorly with two rounded areas separated by a deep longitudinal sulcus in posterior view; dorsal surface of pronotal horn
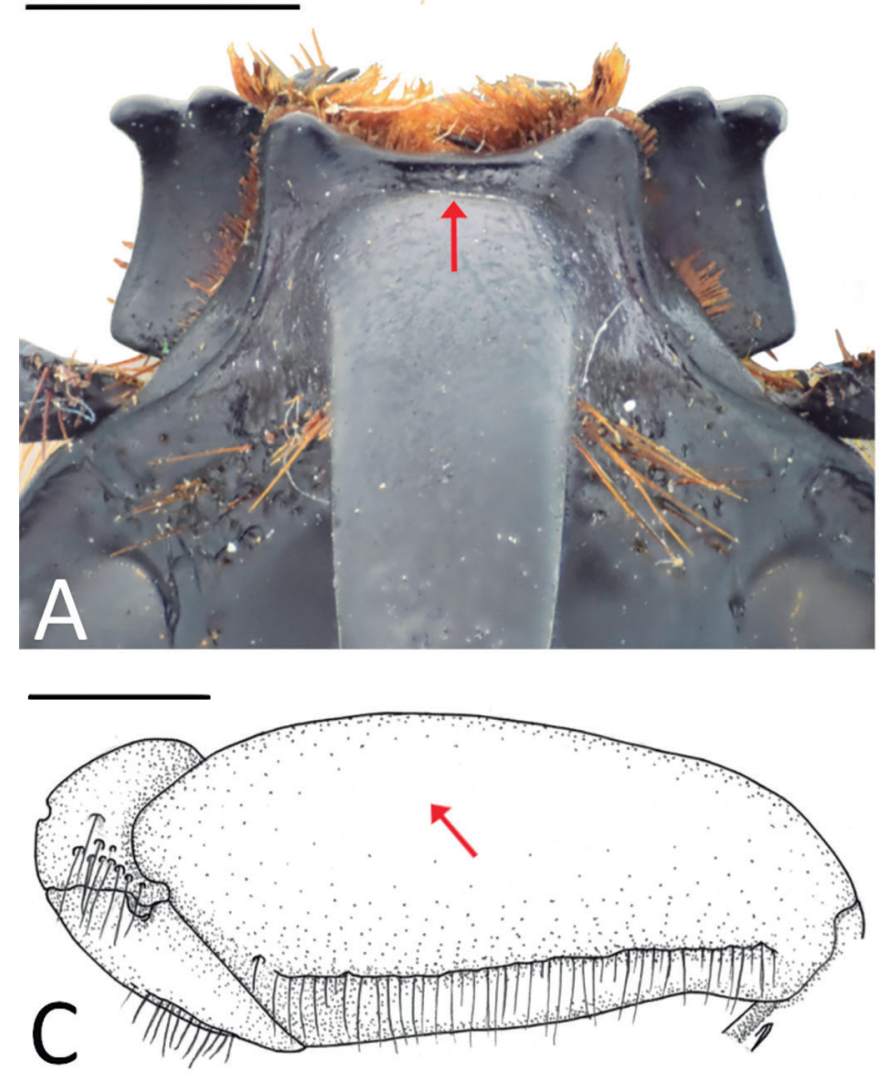

finely punctate, ventral surface densely covered by short, yellowish setae. Pronotal border complete, anteriorly broader at the midline; surface of lateral margin medially with groups of coalescent, C-shaped punctures; anterior surface unequally declivous, declivity near $45^{\circ}$, slightly concave, with a medial groove extended posteriorly to horn base; posterior area with a weak lateral concavity on each side near horn base.

Scutellum: Subtriangular in shape, surface with a V-shaped-grouped, coalescent punctures, and C-shaped punctures among them.

Elytra: Surface completely chagrined, with roughness only observed under high magnifications; sutural striae well visible, remaining discal striae barely impressed; disc finely, irregularly punctate; area above humerus smooth; lateral area bellow humerus with three incomplete rows of large, ocellate punctures; punctures decreasing in size posteriorly.

Legs: Protibiae quadridentate; mesotibiae with one proximal, three medial, and two distal teeth on external surface; metafemora with a row of seven setigerous punctures near to anterior ventral margin (Fig. 3D); metatibiae with one proximal, two medial and two distal teeth on external surface.

Venter: Surface nearly completely setose. Prosternal process triangular, flat in lateral view, prolonged between anterior coxae, with setae confined to the base and apex.
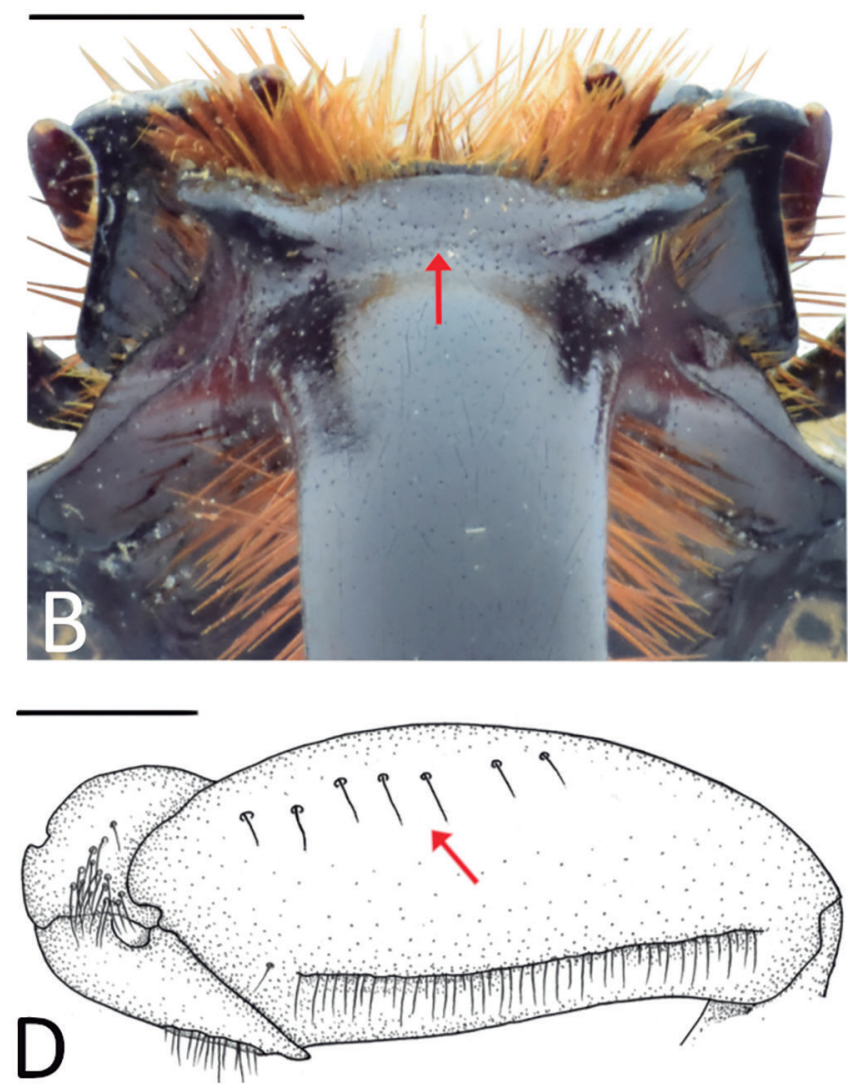

Figure 3. (A-B) Clypeal apex of males, dorsal; (C-D) metafemora of males in ventral view. (A, C) Podischnus sexdentatus (Taschenberg). (B, D) P. limeirai sp. nov. Red arrows indicating clypeal border present (A), absent (B); row of setae absent (C), present (D). Scale bars: $2 \mathrm{~mm}$. 
Abdomen: Ventrite II with a complete row of setae; ventrites III-V with incomplete row of setae; ventrite VI completely bordered by setae at posterior margin; surface of ventrites II-V strongly rugose near to anterior margins, roughness confined to sides, disc nearly smooth, only with few, fine, scattered punctures; ventrite VI rugose at the sides, disc smooth, apex widely emarginate. Tergite VII with arched stridulatory apparatus (Fig. 5D); stridu- latory apparatus formed by two bands of innumerous small tubercles; tubercles transverse, well-marked near the base, scattered about one tubercle of distance, becoming less scattered and finely marked toward apex. Tergite VIII strongly convex in lateral view; surface with rugopunctures on lateral and basal areas, disc finely punctate, glabrous; area near apical margin with a slight concavity on each side; posterior border glabrous.
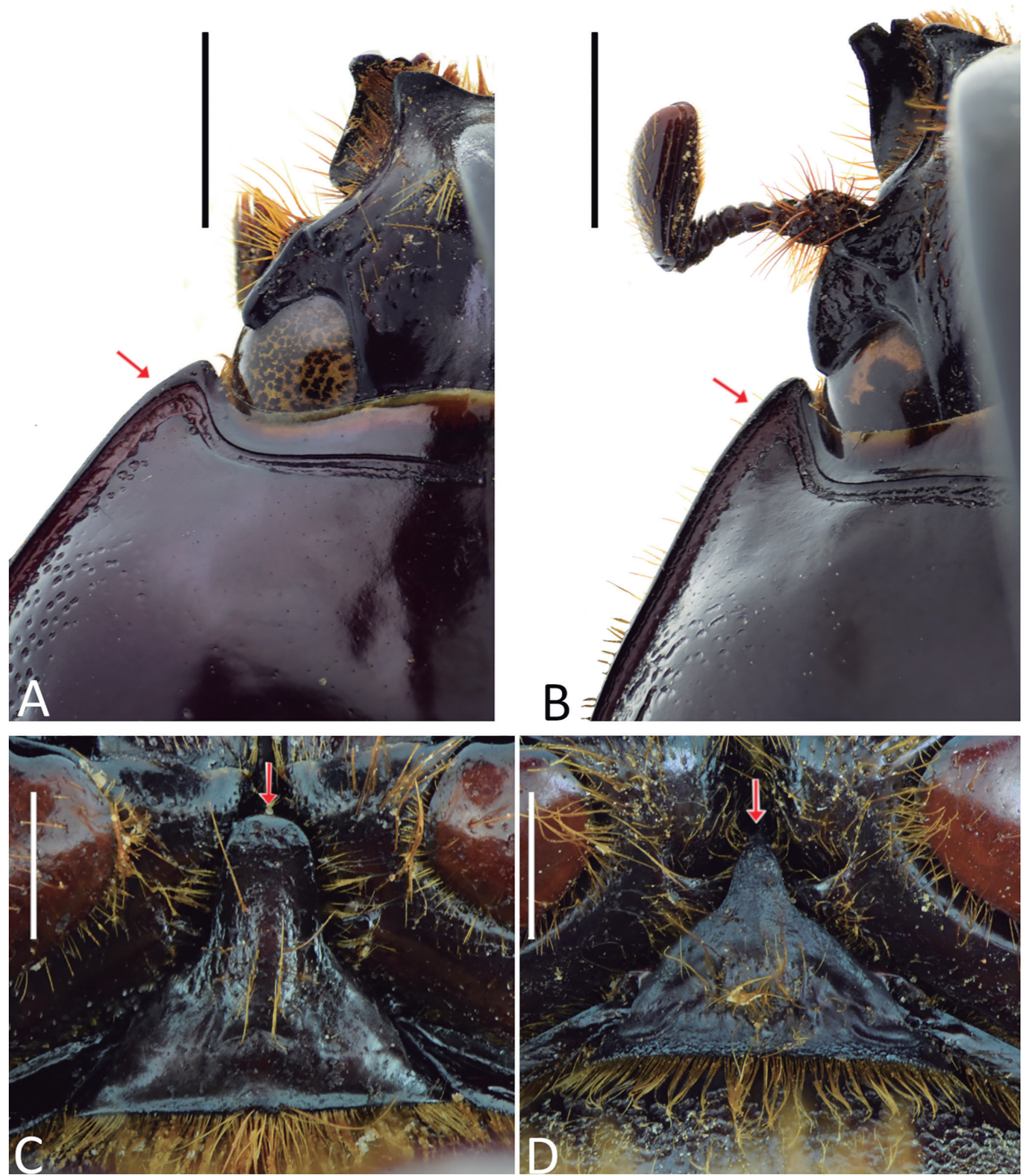

Figure 4. (A-B) Podischnus Burmeister species, left anterior pronotal corner of males, dorsal; (C-D) prosternal process of males, ventral. (A, C) P. sexdentatus (Olivier). (B, D) P. cleidecostae sp. nov. Red arrows indicate: anterior corner rounded in (A), acute in (B); prosternal process long in (C), short in (D). Scale bars: $2 \mathrm{~mm}$. 


\section{Paratypes, male variation}

Differing from the holotype in the following aspects: Body length ranging from $44.0-45.0 \mathrm{~mm}$ and body width from 20.5-21.0.

Head: Cephalic horn with lateral setae almost reaching its midline.

Pronotum: Pronotal medial groove sometimes absent, and pronotal horn sometimes with three longitudinal, posterior sulci.

Legs: Metafemora ventrally with a row of $5-10$ setigerous punctures near the anterior margin.

Abdomen: Basal area of tergite VIII with two transverse bands of setae on each side; posterior border with setae confined to apex.
Aedeagus: Parameres symmetric, laterally narrowed at the outer margins in dorsal view, outer margins rounded posteriorly on apical half, inner margins setose (Fig. 6D); in lateral view with a strong, longitudinal excavation; outer margins visible in ventral view, ventral plate slightly truncated apically (Fig. 7D).

\section{Female (Fig. 8D)}

Very distinct from male holotype in the following characteristics.

Head: Surface completely rugopunctate; clypeus weakly narrowed laterally; frons with setose lateral areas separated by a small, conic, central tubercle.

Pronotum: Horn absent, surface with completely, transversely rugopunctate anterior area; posterior area finely punctate; lateroposterior area with large, sometimes co-
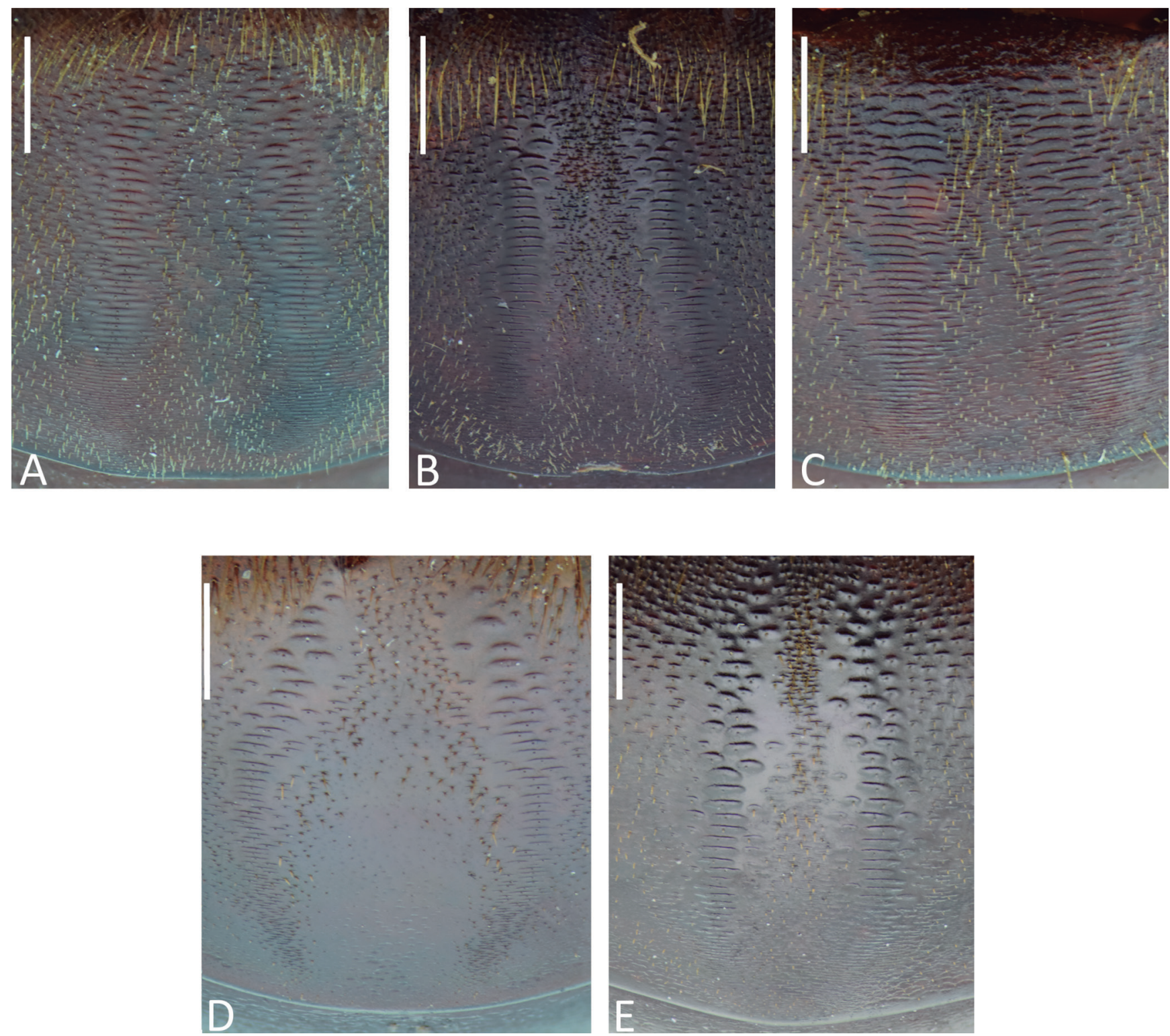

Figure 5. Tergite VII, detail of the stridulatory apparatus of males in Podischnus Burmeister species, dorsal. (A) P. agenor (Olivier). (B) P. sexdentatus (Taschenberg). (C) P. oberthuri Sternberg. (D) P. limeirai sp. nov. (E) P. cleidecostae sp. nov. Scale bars: $2 \mathrm{~mm}$. 
alescent, C-shaped punctures; medial third with two small tubercles; anterior border narrow at the midline (Fig. 9A).

Abdomen: Ventrite VI subtriangular shaped, finely punctate; tergite VIII glabrous, weakly convex compared to male in lateral view.

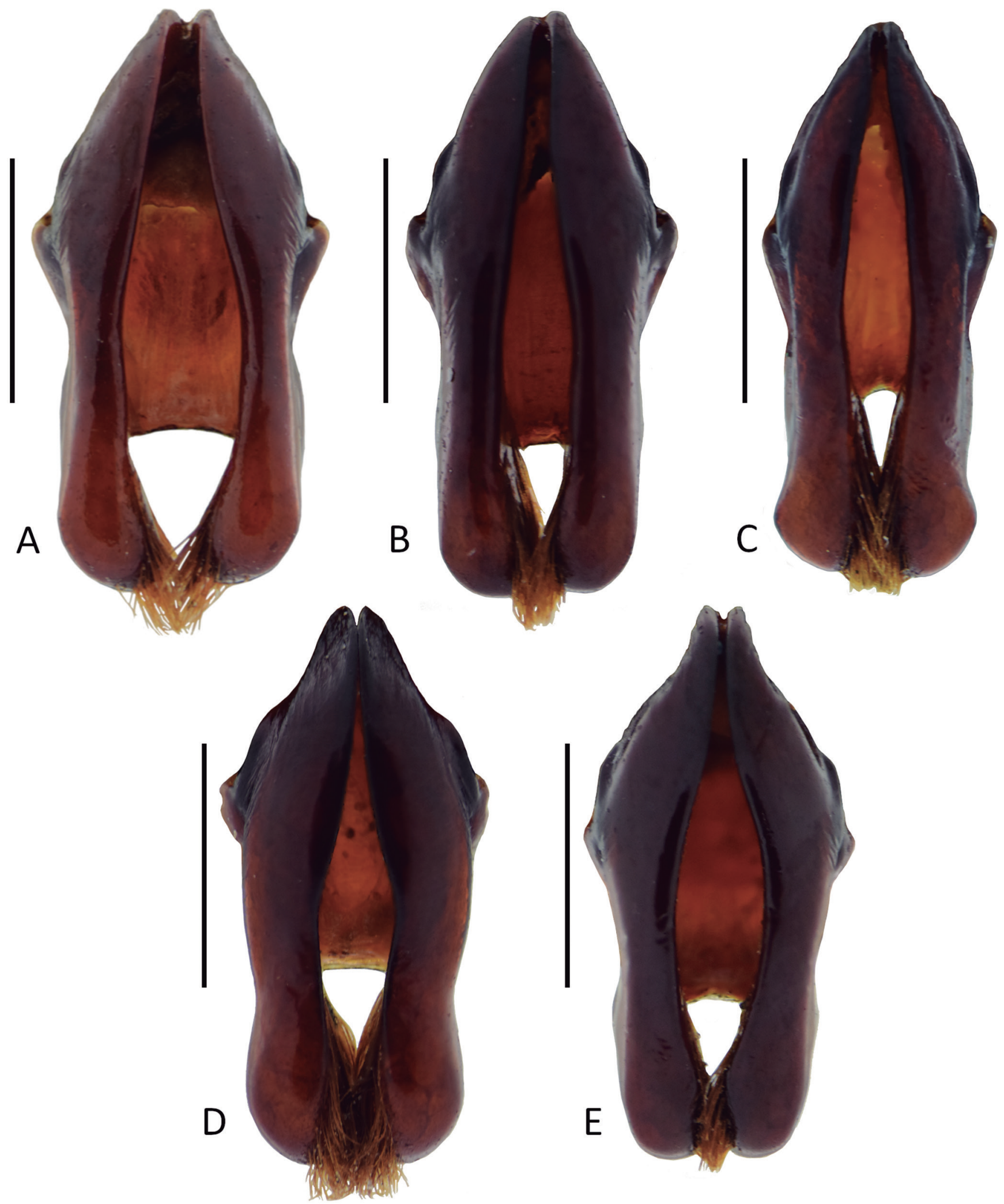

Etymology: The specific epithet "limeirai" is a patronym honoring to Dr. Francisco Limeira de Oliveira, curator of the Coleção Zoológica do Maranhão and the responsible of the current knowledge of the entomological fauna from "Meio Norte" region comprising the states of Maranhão and Piauí, respectively. 
Geographical distribution: Brazil: Maranhão state (Fig. 10).

\section{Podischnus cleidecostae sp. nov. (Figs. 1E; 2E; 4B, D; 5E; 6E; 7E; 10)}

Type material: HOLOTYPE ơ (DZUP), not dissected, labeled: "BRASIL: Acre: Cruzeiro do Sul, IX.1956, R.L. Gonçalves (DZUP)". PARATYPES: 4 males with same data as the holotype (2 $\sigma^{\prime}$ DZUP; $2 \sigma^{\prime}$, CERPE).

Diagnosis: Podischnus cleidecostae sp. nov. is distinguished from other Podischnus species by the following combination of characters: cephalic horn in major males with broad, compressed apex, or with a small subapical tooth in lateral view (Fig. 2E); prosternal process short, confined below the anterior coxae (Fig. 4D); stridulatory apparatus separated by a medial row of setose punctures confined to the base of tergite VIII (Fig. 5E); parameres laterally convergent on basal half (Fig. 6E).

\section{Holotype, male description}

Body length: $45.26 \mathrm{~mm}$.

Body width: $20.28 \mathrm{~mm}$.

Color: Surface dark reddish brown.

Head: Clypeus subtrapezoidal in shape, bidentate at apex; teeth lobed, raised, separated by an emargina-
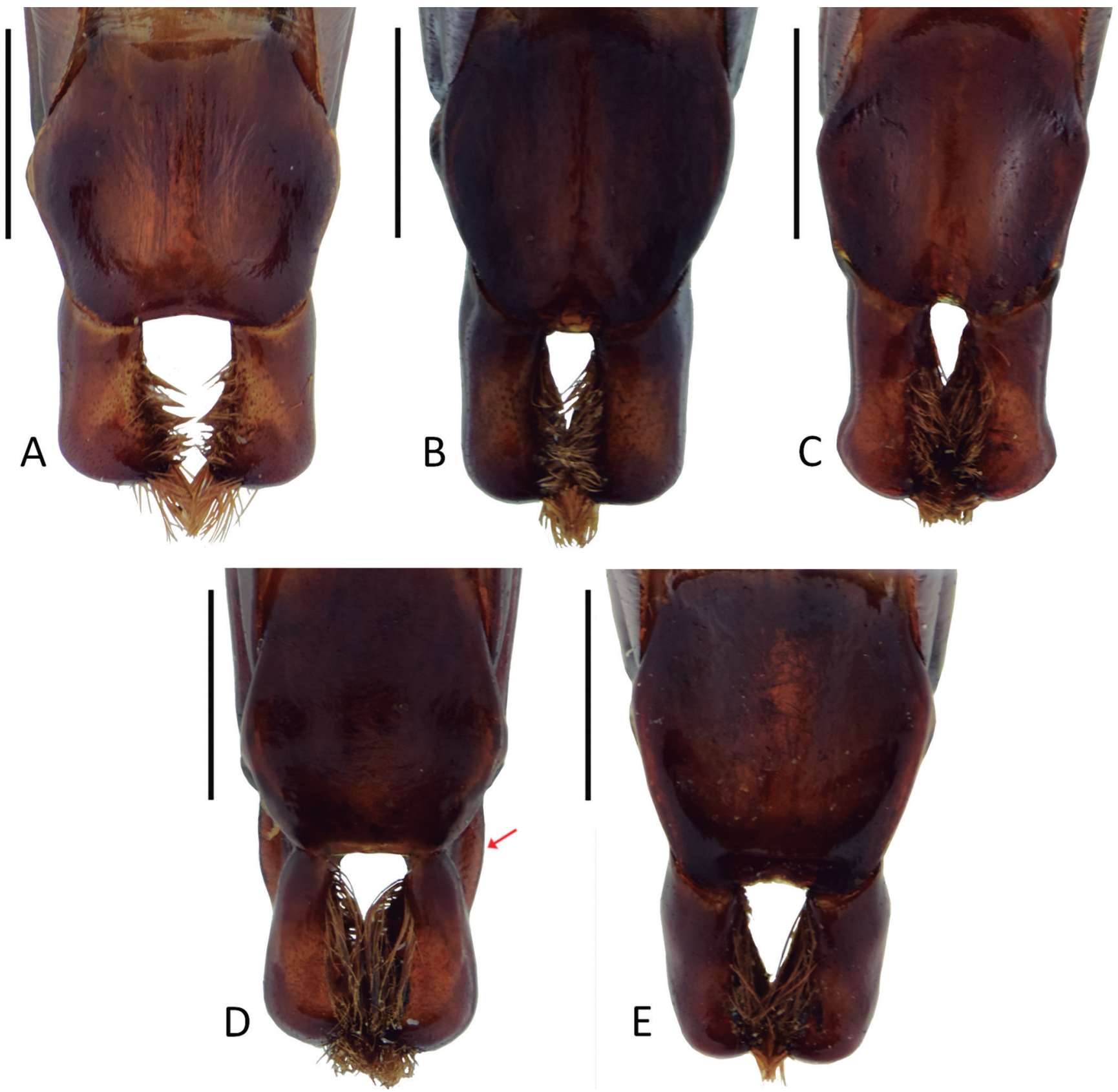

Figure 7. Parameres of Podischnus Burmeister species in ventral view. (A) P. agenor (Olivier). (B) P. sexdentatus (Taschenberg). (C) P. oberthuri Sternberg. (D) P. limeirai sp. nov. (E) $P$. cleidecostae sp. nov. Red arrow indicates outer margins visible in (D). Scale bars: $2 \mathrm{~mm}$. 

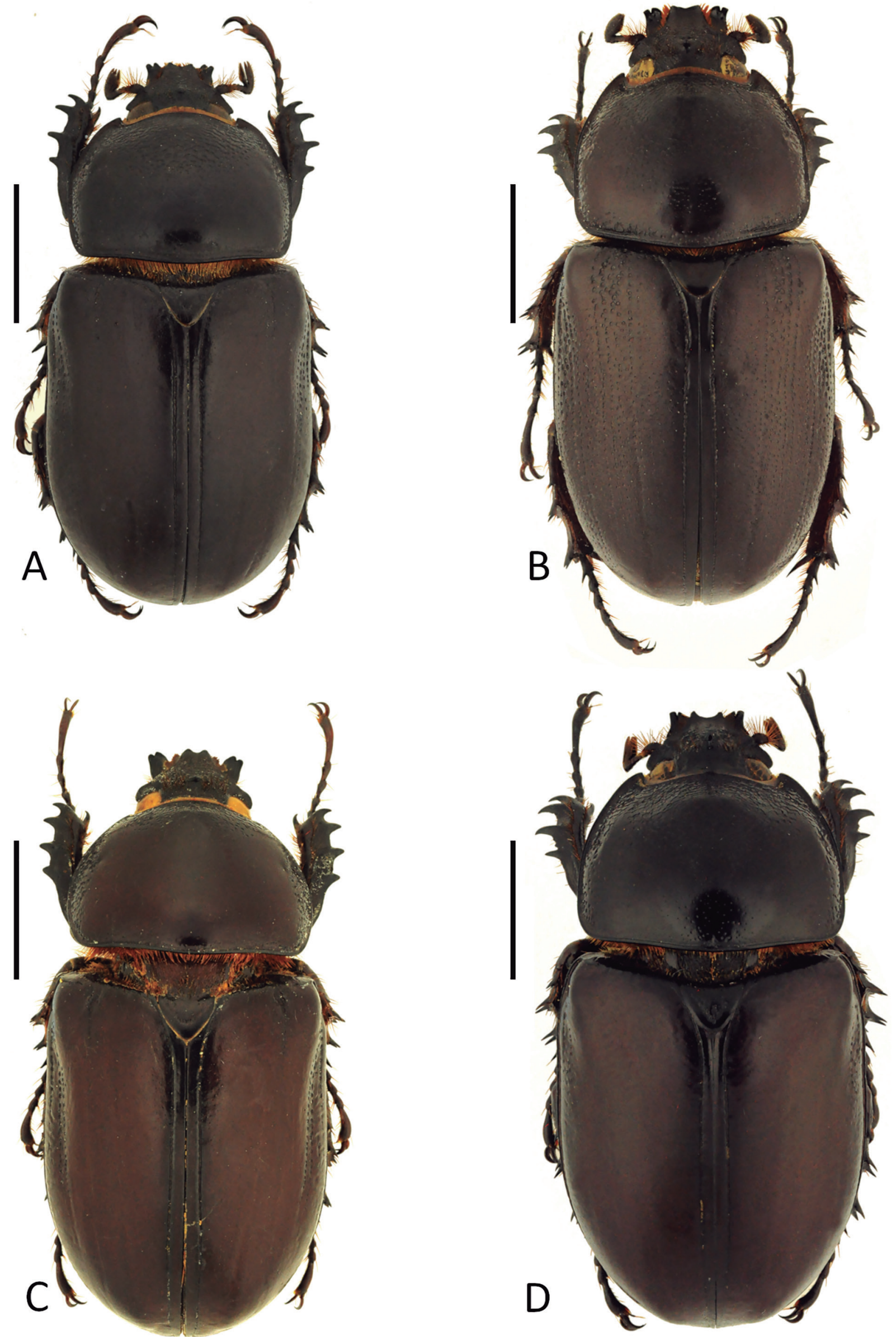

Figure 8. Podischnus Burmeister species (females), habitus dorsal. (A) P. agenor (Olivier). (B) P. sexdentatus (Taschenberg). (C) P. oberthuri Sternberg. (D) P. limeirai sp. nov. Scale bars: $2 \mathrm{~mm}$. 
tion in dorsal view; horn at the subapical clypeal area strong, curved backwards; horn apically compressed, expanded in lateral view, with a small, subapical tooth
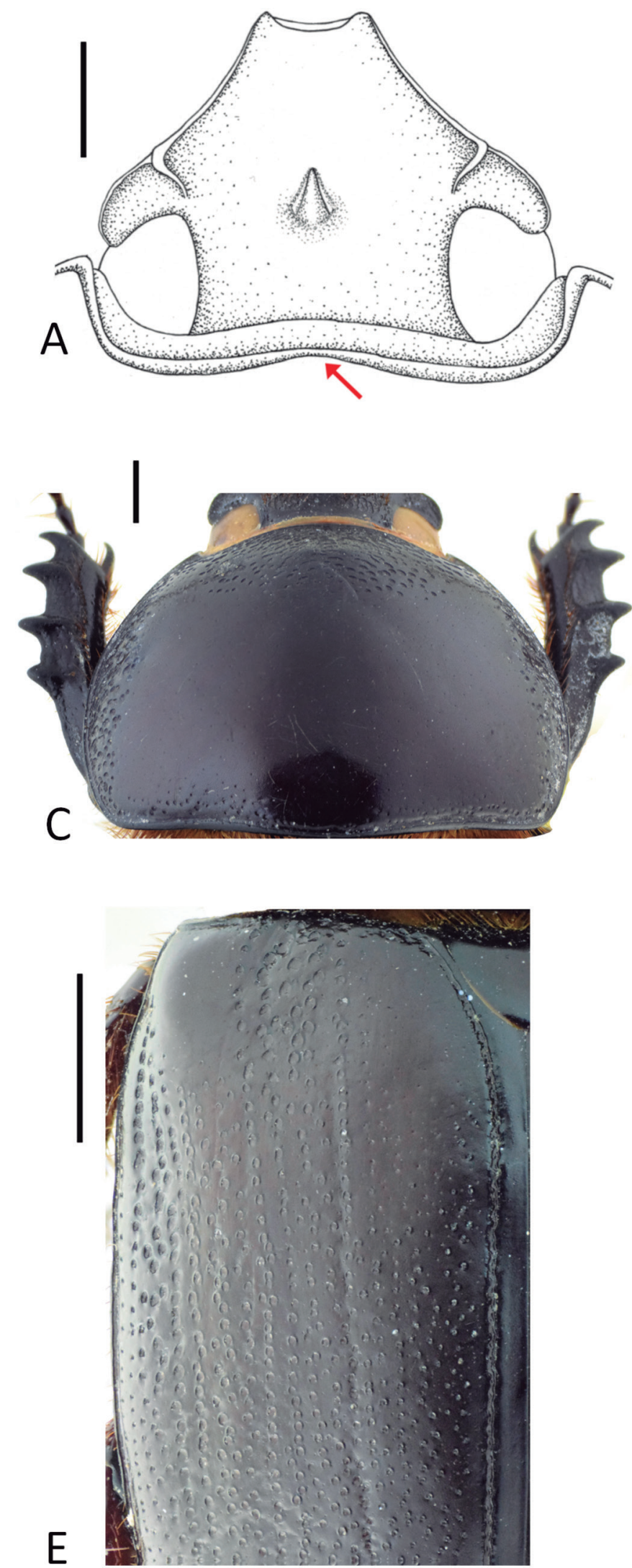

(Fig. 2E); horn base setose at sides, glabrous medially. Frons weakly rugose near the eyes, smooth medially. Eye canthus glabrous, subtriangular in shape, slightly arched
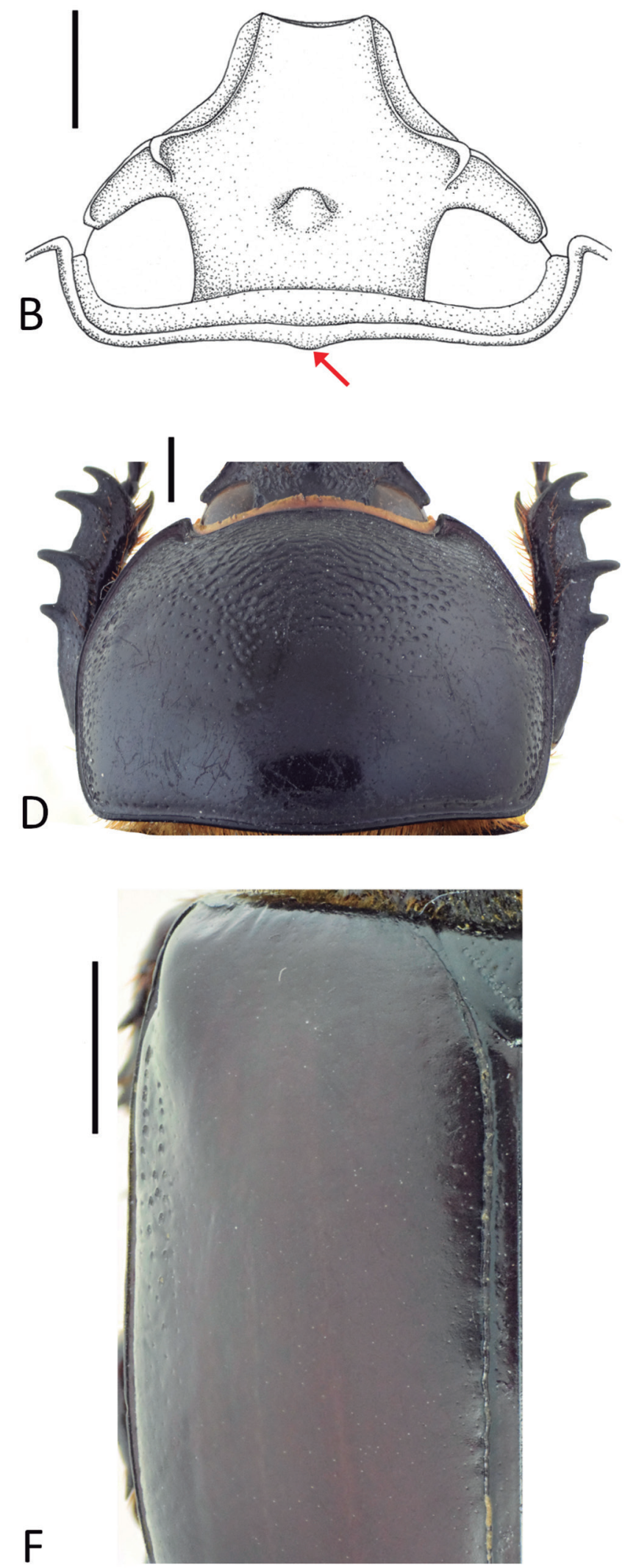

Figure 9. (A-B) Podischnus Burmeister species, heads of females, dorsal. (C-D) Pronotum of females, dorsal. (E-F) Left elytron of females, dorsal. (A) P. limeirai sp. nov. (B, D, F) P. agenor (Olivier). (C) P. oberthuri Sternberg. (E) P. sexdentatus (Taschenberg). Red arrows: medial area of the anterior pronotal border narrow in (A), posteriorly projected in (B). Scale bars: $2 \mathrm{~mm}$. 
backwards. Antennae with 10 antennomeres; club subequal in length to antennomeres 2-7. Mandibles bidentate at apex. Mentum eliptical in shape, disc smooth, moderately covered by setose punctures on sides; apex widened.

Pronotum: Anterior angles strongly acute (Fig. 4B); medial portion of discal area obtusely declivous in lateral view, with a weakly marked ridge extended to horn base in dorsal view; posterior area with a horn, projected backwards in lateral view, apically broad; horn apex finely punctate, strongly emarginated anteriorly, densely setose ventrally, at middle with a pit, extending posteriorly in a medial sulcus (Fig. 1E). Lateral surface strongly rugopunctate at the midline.

Scutellum: Moderately punctate; punctures C-shaped, irregularly scattered.

Elytra: Surface almost completely covered by fine punctures; area above humerus with a row of six large, C-shaped punctures; lateral area bellow humerus with three incomplete rows of punctures; first and second rows extending until posterior area, punctures decreasing in size towards posterior area; third row with large punctures only.

Legs: Protibiae quadridentate. Mesotibiae with three medial and two distal teeth on external surface. Metatibia with four medial and three distal teeth on external surface.

Venter: Prosternal process short, triangular, confined below mesocoxae; central area with a small, setose tubercle.

Abdomen: Ventrite II with a complete medial row of transverse, setose punctures; ventrites III-V with rows confined to sides; ventrite VI covered by setae on posterior margin. Ventrites II-V rugose on sides, smooth on disc; ventrite VI rugose near anterior margin. Tergite VII with stridulatory apparatus formed by two parallel carinate bands; carinae well-marked and tubercle-like in shape near the base, gradually becoming finely marked and more transverse towards apex; basal area between carinae with a medial row of setose punctures, becoming irregularly scattered towards apex (Fig. 5E). Tergite VIII strongly rugose on sides near apical margin; discal area weakly punctate; transversal area near basal margin moderately rugopunctate.

\section{Paratypes, male variation}

Differing from holotype in the following
haracteristics.

Body length: 44.99-37.27.

\section{Body width: 19.77-16.92.}

Head: Minor male with clypeal apex deeply emarginated; cephalic horn short, with no modifications; frons strongly punctate on sides. Cephalic horn in major males lacking apical expansion in lateral view, only with a small subapical tooth, or only with enlarged apex, with no subapical tooth.

Pronotum: Minor male with horn not as broad as in major males, tubercle-like shaped; dorsal horn surface with pit sometimes absent.

Scutellum: Weakly punctate or with V-shaped punctures.

Legs: Meso- and metatibiae with a small proximal tooth on external surface.

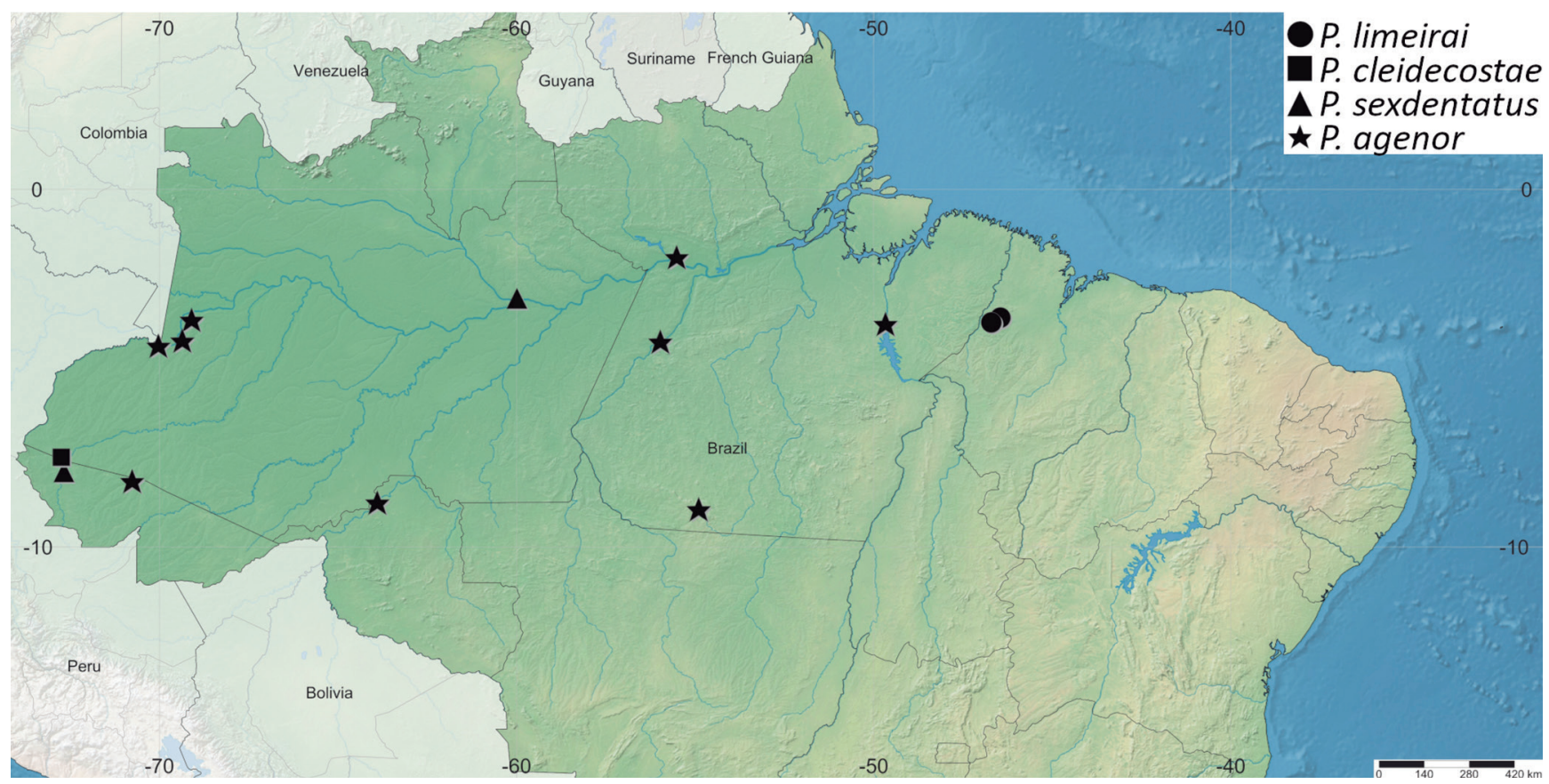

Figure 10. Geographical distribution of Podischnus Burmeister species from the Brazilian Amazon. 
Aedeagus: Parameres symmetric; apical half with outer margins convergent in dorsal view (Fig. 6E); inner margins with subapical setae; ventral plate weakly emarginate at apex (Fig. 7E)

Female: Unknown
Etymology: The specific epithet is a patronym honoring to Prof. Dr. Cleide Costa for her $80^{\text {th }}$ anniversary, as well as for her tremendous contribution to the systematics of Neotropical Coleoptera.

Geographical distribution: Brazil: Acre state (Fig. 10).

\section{Identification key to adults of Podischnus species}

1. Head and pronotum with a strong horn in lateral view (Figs. 2A-E); pronotal surface nearly smooth anteriorly. (males) 2

- Head and pronotum without horns, only with small tubercles (Figs. 9A-B); pronotal surface strongly rugose and simply convex (Figs. 9C-D)............. (females) 6

2. Clypeal apex flanged in front of the cephalic horn in dorsal view (Fig. 3A); metafemora glabrous near the anterior margin (Fig. 3C); tergite VII with subparallel stridulatory bands (Figs. 8A-C, E); outer margin of parameres not visible in ventral view (Figs. 7A-C, E).

- Clypeal apex not flanged in front of cephalic horn in dorsal view (Fig. 3B); metafemora with a row of setae near anterior margin (Fig. 3D); tergite VII with arched stridulatory bands (Fig. 5D); parameres with outer margins visible in ventral view (Fig. 7D). Brazil. ... Podischnus limeirai sp. nov.

3. Pronotal anterior angles rounded (Fig. 4A); prosternal process extended between anterior coxae (Fig. 4C); area between stridulatory bands of tergite VII with irregularly scattered setae (Figs. 5A-C); parameres in dorsal view as in the (Figs. 6A-C), in ventral view as in the (Figs. 7A-C)

- Pronotal anterior angles acute (Fig. 4B); prosternal process short, not prolonged between anterior coxae (Fig. 4D); tergite VII with stridulatory bands separated by a mid-row of setose punctures (Fig. 5E); apical half of parameres with convergent outer margins in dorsal (Fig. 6E) and ventral views (Fig. 7E). Brazil ........ ... Podischnus cleidecostae sp. nov.

4. Pronotal horn wide in dorsal view (Figs. 1A-B); stridulatory bands of tergite VII as in (Figs. 5A-B); parameres with subparallel outer margins in dorsal (Figs. 6A-B) and ventral views (Figs. 7D-B)

- Pronotal horn narrow in dorsal view (Fig. 1C); stridulatory bands of tergite VII as in Fig. 5C; parameres clearly rounded at outer margins near apex in dorsal view (Fig. 6C). Ecuador, Peru and Bolivia

...Podischnus oberthuri Sternberg

5. Area between stridulatory bands densely punctate, punctures observed under high magnification fine (Fig. 5B); ventral plate of parameres with rounded apex (Fig. 7B). Colombia, Brazil, Ecuador and Peru Podischnus sexdentatus (Taschenberg)

- Area between stridulatory bands without fine punctures, only with weak transverse wrinkles (Fig. 5A); ventral plate of parameres widely emarginate (Fig. 7A). Mexico to Brazil. ..Podischnus agenor (Olivier)

6. Anterior pronotal border not narrowed at the midline (Fig. 9B) Podischnus limeirai sp. nov. (Fig. 8D).

- Anterior pronotal border narrowed at the midline (Fig. 9A). Brazil 7

7. Pronotal punctures extend to posterior area (Fig. 9D)

- Pronotal punctures confined to anterior area (Fig. 9C). Ecuador, Peru and Bolivia Podischnus oberthuri Sternberg (Fig. 8C)

8. Elytral surface densely punctate, punctures strong (Fig. 9E). Colombia, Brazil, Ecuador and Peru — Elytral surface almost smooth (Fig. 9F). Mexico to Brazil .... Podischnus sexdentatus (Taschenberg) (Fig. 8B) Podischnus agenor (Olivier) (Fig. 8A)

\section{DISCUSSION}

Podischnus limeirai sp. nov. and P. cleidecostae sp. nov. are unusual species because the pronotal horn is bent backwards, and this feature is unique among the other species of the genus. Besides, among the material studied we noticed new features to identify $P$. agenor and $P$. sexdentatus, two species so far distinguished only by the basal punctures on the sides of the pronotal horn (absent in $P$. agenor, present in $P$. sexdentatus) (Endrödi, 1985; Gasca-Álvarez et al., 2008; Sanabria-García et al., 2012). The stridulatory apparatus and the ventral plate of the parameres (see the identification key above) are consistent features to differentiate both species. The stridulatory apparatus is an important new character for the identification of Podischnus species.

Podischnus limeirai sp. nov. deserves special attention because so far the known distribution is restricted to the easternmost limit of the Amazonian biome. This means not only a new state record of the genus (Maranhão) but also an expansion of its distribution to the east. Moreover, Podischnus limeirai sp. nov. is the unique species of the genus restricted to an endemism area within the Amazonian biome, and does not occur in sympatry with any other Podischnus species.

The Belém endemism area where $P$. limeirai sp. nov. occurs is localized at the Pará biogeographic province sensu Morrone (2006). It is distributed from eastern Pará state to western Maranhão state, bounded to the west by the Tocantins river (Pará state) and to the east by the Pindaré river (Maranhão state) (Almeida \& Vieira, 2010). According to da Silva et al. (2005), the Amazon is a biogeographical heterogeneous area constituted by a set of eight endemism centers delimited by major rivers, each of them with its particular evolutionary history. Studies based on distribution of different taxa of lizards (ÁvilaPires, 1995), primates (Silva \& Oren, 1996), amphibian (Ron, 2000), birds (Silva et al., 2002) and also riodinid butterflies (Hall \& Harvey, 2002) support this delimitation of Amazonian endemism areas. Gasca-Alvarez et al. (2008) showed that $P$. sexdentatus occurs in the states of Acre and Amazonas. Podischnus agenor has a more eastern distribution within the Amazon, but extending up to the west of Tocantins river, not reaching the Belém endemism area. Ratcliffe (1976) inferred that the complex networks of the Amazonian rivers, which raised on intergla- 
cial periods, are the responsible for the subspeciation of Strategus surinamensis Burmeister, 1847 in S. surinamensis surinamensis Burmeister, 1847 (distributed north of the Amazon River), and S. s. hirtus Sternberg, 1910 (distributed south of the Amazon River). This climatic event can be associated with the allopatric speciation and distribution of $P$. limeirai sp. nov. The Belém endemism area is the most deforested among the Amazon endemism areas, with loss of $124,801 \mathrm{~km}^{2}$, over $62.2 \%$ of area, occasioned mainly by agricultural expansion, being classified as critically endangered (Braz et al., 2016).

The type locality of $P$. limeirai sp. nov. is situated within the "Reserva Biológica do Gurupi" (Rebio) and "Terra Indígena Awá/Guajá", Gurupi region, Maranhão state (see above). This region hosts endangered and endemic mammalian and birds (Oren \& Roma, 2011; Oliveira et al., 2011). The Rebio Gurupi and adjacent indigenous lands are the last continuous Amazon forests remnants of Maranhão state, being considered one of the most endangered areas of Brazilian Amazon Forest in 2011 (Oliveira, 2011). The conservation of Gurupi region is determinative for maintenance of a variety of unique, endemic or threatened species (Oliveira, 2011). Therefore, we propose to include $P$. limeirai sp. nov. in the Red List of Threatened Species (IUCN), according to its endemic distribution mentioned above, in Near Threatened (NT) category according the (IUCN, 2012) Red List criteria.

\section{ACKNOWLEDGMENTS}

We would like to thank especially Dr. Francisco Limeira-de-Oliveira (CESC/UEMA) to make available plenty Coleoptera material from Maranhão state including the species described here. The curators of the collections studied are also thanked for the loaned material. Dr. Sônia Casari and Gabriel Biffi (MZSP) are thanked for the invitation to collaborate with this special number of the journal. This study was founded in part by the Coordenação de Aperfeiçoamento de Pessoal de Nível Superior - Brasil (CAPES) - code 001 to PRMD, and Conselho Nacional de Desenvolvimento Científico e Tecnológico (CNPq), Edital Universal, process number 449366/2014-6 to PCG.

\section{REFERENCES}

Almeida, A.S. \& Vieira, I.C.G. 2010. Centro de endemismo Belém: status da vegetação remanescente e desafios para a conservação da biodiversidade e restauração ecológica. Revista de Estudos Universitários, Amazonia, 36(3): 95-111.

Ávila-Pires, T.C.S. 1995. Lizards of Brazilian Amazonia (Reptilia: Squamata). Zoologische Verhandelingen, 299: 1-706.

Braz, L.C.; Pereira, J.L.G.; Ferreira, L.V. \& Thalês, M.C. 2016. A situação das áreas de endemismo da Amazônia com relação ao desmatamento e às áreas protegidas. Boletim de Geografia, Maringa, SP, 34(3): 45-62.

Cherman, M.A. \& Morón, M.A. 2014. Validación de la familia Melolonthidae Leach, 1819 (Coleoptera: Scarabaeoidea). Acta Zoológica Mexicana, Nueva Série, 30(1): 201-220.
Eberhard, W. 1979. The function of horns in Podischnus agenor (Dynastinae) and other beetles. In: Blum, M.S. \& Blum, N.A. Sexual selection and reproductive competition in insects. New York, Academic Press. p. 231-258.

Endrödi, S. 1976. Monographie der Dynastinae 5. Tribus: Oryctini (die Arten von Amerika) (Coleoptera: Melolonthinae). Folia Entomologica Hungarica, 29: 9-174.

Endrödi, S. 1985. The Dynastinae of the world. Dordrecht, W. Junk.

Gasca-Álvarez, H.J.; Fonseca, C.R.V. \& Ratcliffe, B.C. 2008. Synopsis of the Oryctini (Coleoptera: Scarabaeidae: Dynastinae) from the Brazilian Amazon. Insecta Mundi, Gainesville, 61: 1-62.

Grossi, P.C. \& Vaz-de-Mello, F.Z. 2019. Catálogo taxonômico da fauna do Brasil. Available at: http://fauna.jbri.gov.br/fauna/faunadobrasil/145602. Access in: 11/08/2019.

Hall, J.P.W. \& Harvey, D. 2002. The phylogeography of Amazonia revisited: new evidence from riodinid butterflies. Evolution, 56(7): 1489-1497.

International Union for Conservation of Nature (IUCN). 2012. Guidelines for application of IUCNRed List criteria a tregional and national levels, version 4.0. Disponível em: https://www.iucn.org/content/guidelines-applicationiucn-red-list-criteria-regional-and-national-levels-version-40.

Latreille, P.A. 1813. Insectes de l'Amérique équinoxiale, recueillis pendant le Voyage de Mm. de Humboldt et Bonpland. In: Humboldt, F.H.A. \& Bonpland, A.J.A. Voyage aux regions equinoxial du nouveau continente, fait em 1799-1804. Recueil d'observations de Zoologie et Anatomie Comparée... Paris. v. 2.

Lawrence, J.F.; Slipinski, A.; Seago, A.E.; Thayer, M.K.; Newton, A.F. \& Marvaldi, A.E. 2011. Phylogeny of the Coleoptera based on morphological characters of adults and larvae. Annales Zoologici, 61: 1-217.

Morrone, J.J. 2006. Biogeographic areas and transitions zones of Latin America and the Caribbean Islands based on panbiogeographic and cladistic analyses of the entomofauna. Annual Review of Entomology, 51: 467-494.

Neita-Moreno, J.C. \& Orozco, J. 2009. Larval and pupal descriptions for the genera Podischnus and Heterogomphus (Scarabaeidae: Dynastinae: Oryctini). Zootaxa, 2168: 34-44.

Oliveira, T.G. 2011. Alerta vermelho à conservação da última fronteira da Amazônia Tocantina: avaliação do estado de conservação do Gurupi e da Amazônia Maranhense. In: Martins, M.B. \& Oliveira, T.G. Amazônia Maranhense: diversidade e conservação. Belém, Museu Paraense Emílio Goeldi. p. 284-295.

Oliveira, T.G.; Júnior, J.S.S.; Dias, P.A.; Quixaba-Vieira, 0.; Gerude, R.G.; Giusti, M. \& Pereira, A.P. 2011. Mamíferos da Amazônia Maranhense. In: Martins, M.B. \& Oliveira, T.G. Amazônia Maranhense: diversidade e conservação. Belém, Museu Paraense Emílio Goeldi. p. 252-267.

Olivier, A.G. 1789. Entomologie, ou histoire naturelle des insects, avec leurs caractères génériques et specifiques, leur description, leur synonymie, et leur figure enluminée. Coléoptères. Paris, Baudouin. v. 1.

Oren, D.C. \& Roma, J.C. 2011. Composição e vulnerabilidade da avifauna da Amazônia Maranhense, Brasil. In: Martins, M.B. \& Oliveira, T.G. Amazônia Maranhense: diversidade e conservação. Belém, Museu Paraense Emílio Goeldi. p. 221-251

Prell, H. 1911. Beiträge zur Kenntnis der Dynastinen. Annales de la Société Entomologique de Belgique, 55: 198-210.

Ratcliffe, B.C. 1976. A revision of the genus Strategus (Coleoptera: Scarabaeidae). Bulletin of the University of Nebraska State Museum, 10: 93-204.

Ratcliffe, B.C. \& Cave, R.D. 2006. The dynastine scarab beetles of Honduras, Nicaragua and El Salvador (Coleoptera: Scarabaeidae: Dynastinae). Bulletin of the University of Nebraska State Museum, 21: 1-424.

Ron, S.R. 2000. Biogeographic area relationship of lowland neotropical rain forest based on raw distributions of vertebrate groups. Biological Journal of the Linnean Society, 71: 379-402. 
Sanabria-García, R.; Gasca-Álvarez, H.J. \& Amat-García, G. 2012. Sinopsis de la tribo Oryctini (Coleoptera: Scarabaeidae: Dynastinae) de Colombia. Insecta Mundi, 0276: 1-64.

Shorthouse, D.P. 2010. Simplemappr, an online tool to produce publicationquality point maps. Available at: http://www.simplemappr.net. Access in: 08/03/2019.

Silva, J.M.C. \& Oren, D.C. 1996. Application of parsimony analysis of endemicity (PAE) in Amazon biogeography: an example with primates. Biological Journal of the Linnean Society, 59: 427-437.

Silva, J.M.C.; Novaes, F.C. \& Oren, D.C. 2002. Differentiation of Xiphocolaptes (Dendrocolaptidae) across the river Xingu, Brazilian Amazonia: recognition of a new phylogenetic species and biogeographic implications. Bulletin of the British Ornithologists' Club, 122(3): 185-194.

Silva, J.M.C.; Rylands, A.B. \& Fonseca, G.A.B. 2005. 0 destino das áreas de endemismo da Amazônia. Megadiversidade, 1: 124-131.

Sternberg, C. 1907. Neue Dynastiden-Arten. Stettiner Entomologische Zeitung, 68: $343-360$.

Taschenberg, E.L. 1870. Neue Käfer aus Colombien und Ecuador. Zeitschrift für die Gesammten Naturwissenschaften, 1: 177-199. 